\title{
Climbing the Ladder of Performance: Are Psychological Contract and Organizational Commitment Steps?
}

Leticia Gomes Maia ${ }^{1}$

Antonio Virgilio Bittencourt Bastos ${ }^{2}$

Banco Central do Brasil, Brasília, DF, Brazil $1^{1}$ Universidade Federal da Bahia, Salvador, BA, Brazil ${ }^{2}$

Received 13 April 2018. This paper was with the authors for three revisions. Accepted 2 April 2019. First published online 15 April 2019.

Takeyoshi Imasato was the associate editor for this article.

Editorial assistant: Luciane Kato Kiwara

Editor-in-chief: Carlo Gabriel Porto Bellini 


\begin{abstract}
Low attrition and high job security in public organizations make the risk low for consequences of performing poorly. Climbing the ladder of job performance, what are the steps that should be in mind? The effects of fulfillment of the psychological contract and of affective organizational commitment on job performance were examined in a longitudinal study with employees and their line managers in a Brazilian public sector agency. We tested three models of mediation, aiming to better explain variance in job performance. This research design with employees and their bosses $(\mathrm{N}=202)$ relieves common method bias and demonstrates in a robust and unique way, through a study carried out over two years, the effects of the fulfillment of the psychological contract on in-role job performance as well as the role of organizational commitment in this process. We found that fulfillment of the psychological contract explained variance in job performance, while commitment did not. However, the addition of organizational commitment as a mediating variable increased the explanatory power of the psychological contract. In our metaphor, psychological contract would be a significant step on the ladder, while commitment would be the difference in how much an individual can stretch his/her arms to reach the best job performance.
\end{abstract}

Key words: performance appraisal; job performance; organizational commitment; psychological contract; longitudinal research design. 


\section{Introduction}

Job performance has an essential economic function for organizations and carries out an important psychological function for employees as an element in the construction of their personal identity and their inclusion in social groups, including at work. For organizations, knowledge about employee performance and the factors that influence it represent a competitive advantage. Specifically in public organizations, the situation of their employees offers a series of peculiar characteristics for job performance, such as job security afforded, and therefore this knowledge could be even more valuable. Low attrition and high job security make the risk low for consequences of performing poorly. How can performance improvement be stimulated without the possibility of offering different benefits or payment? It is important to note that the public sector has many similarities across the world, thus our results and reflections about the possible impacts that the individual perception of psychological contract and affective commitment promotes on the process of human resource and job performance management are likely to hold true in different contexts.

Psychological contract refers to how the employee perceives his/her own obligations towards the employer as well as the obligations of the employer towards themselves, while affective organizational commitment (AOC) highlights the emotional nature of the attachment between the individual and the organization. Our goal is to answer whether the organizations can expect employees to perform better depending on the level of fulfillment of the psychological contract and the level of AOC of employees.

Job performance is a complex behavioral phenomenon. Its complexity may be a reason why its theoretical concept has considerable heterogeneity, as does its methodological operationalization, with a plethora of associated measures; however, the concept is one of the most investigated in the area of organizational behavior. The epistemological difficulties of research into job performance have made the study of its antecedents scarce and inconclusive. In this study, we conduct an empirical test of the association between the fulfillment of the psychological contract, AOC, and job performance. This test will take into account both parties in the psychological contract: how the employees perceive the fulfillment of employer obligations, and how they perceive the fulfillment of their own obligations towards the organization.

A research design with employees and their bosses $(\mathrm{N}=202)$ and a time lag between the measurement of the predictor and criterion variables relieves common method bias and aims to demonstrate in a robust and unique way, by applying structural equation modeling through a study carried out over two years, the effects of the fulfillment of the psychological contract on inrole job performance and the role of organizational commitment in this process.

The aim of this article is to investigate the effects of the fulfillment of the psychological contract and AOC on job performance in a longitudinal study. The way we chose to achieve this aim is by comparing three models of mediation: in the first model of full mediation, there is no direct link between the psychological contract and job performance; in the second model of partial mediation, all variables are interconnected; and in the third model, there is no mediation and 
no link between fulfillment of the psychological contract and AOC. Our question is whether the fulfillment of psychological contract and AOC are two notable steps on the ladder of job performance.

\section{Theoretical Background}

The definition of job performance is usually divided into in-role and extra-role performance (Riketta, 2008). The first theories on job performance in the context of Taylorism and Fordism tended to emphasize task performance, which, like in-role performance, focuses on the fulfilling of tasks or on the outcomes of work. Task performance relates to the individual's proficiency in contributing to the technical core of a position or occupation or proficiency in performing the technical and instrumental requirements of each job behavior (Borman \& Motowidlo, 1993). Inrole performance is difficult to operationalize since the outcomes or the tasks may depend on other factors besides those under the control of the individual. Therefore, the models consider only the behaviors or actions that are under the control of the individual, especially in a process of evaluation, that have consequences, so individuals can be punished or recognized for their results. Moreover, in-role performance ultimately devalues other behaviors that, although not directly linked to the implementation of the tasks, also contribute to the achievement of organizational objectives. In this paper, job performance refers to behavior that is relevant to the objectives of the organization and that can be measured in terms of the proficiency level (or contribution to the goals), which is represented by a particular action or set of actions (Campbell, 1999). There is a variety of factors that can be combined to determine job performance. The related constructs are located at different levels, such as individual, group, organization, and society. Two of the predictors of job performance are psychological contract and organizational commitment (Bal, Chiaburu, \& Jansen, 2010; Conway \& Coyle-Shapiro, 2011).

Psychological contract refers to beliefs concerning the terms and conditions of a reciprocal exchange agreement between an individual and the organization (Rousseau, 1995). A central aspect in the definition of the psychological contract is the idea of two-sided exchange and reciprocity (Conway \& Briner, 2005). The employee perceives his/her own obligations towards the employer as well as the obligations of the employer towards themselves. In investigating the consequences of the psychological contract, the focus should be on the state of the psychological contract, which is determined according to the fulfillment of its contents. One of the consequences of fulfillment of the psychological contract is organizational commitment, which refers to "the relative strength of an individual's identification with and involvement in a particular organization” (Mowday, Porter, \& Steers, 1982, p. 27). There are many studies relating psychological contracts and organizational commitment. Some studies found that fulfillment of the psychological contract is related positively to organizational commitment (e.g., McInnis, Meyer, \& Feldman, 2009; Sturges, Conway, Guest, \& Liefooghe, 2005). On the other hand, studies investigating the relationship between psychological contracts and job performance are less numerous. Conway and Coyle-Shapiro (2011) found that the strength of the relationship between the fulfillment of the psychological contract and performance increased over time. The results of Turnley, Bolino, Lester and Bloodgood (2003) suggest that psychological contract fulfillment is positively related to in-role performance and organizational citizenship behavior. 
Bal, Chiaburu and Jansen's (2010) study showed that the state of the psychological contract has considerable impact on work performance, while Lester, Turnley, Bloodgood and Bolino (2002) found that the greater the breach perceived by the employees, the lower their job performance. The significant and direct effects of the psychological contract on in-role performance were also supported by the studies by Johnson and O'Leary-Kelly (2003) and Restubog, Bordia, Krebs and Tang (2005). Our first hypothesis is that when employees feel that their psychological contracts have been fulfilled, they will become more committed to the organization, and they will then perform better. This hypothesis investigates the direct effects of fulfillment of the psychological contract on AOC, its indirect effects on job performance, and the direct effects of AOC on job performance. In this model, there is no direct link between psychological contract and job performance, as shown in Figure 1.

Hypothesis 1: Affective organizational commitment mediates the relationship between psychological contract fulfillment and job performance.

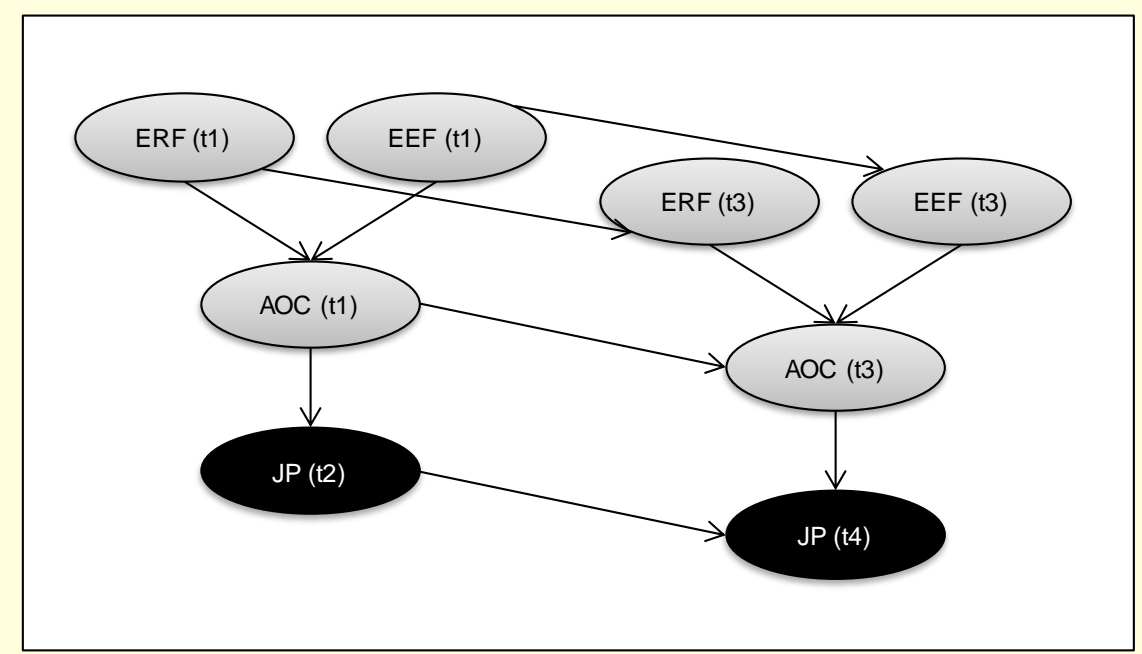

Figure 1. Full mediation

Note. $E R F=$ Employer Obligations Fulfillment; $E E F=$ Employee Obligations Fulfillment; $A O C=$ Affective Organizational Commitment; JP= Job Performance; before a number indicates Time (e.g., $\mathrm{t} 1$ = Time1).

While there is some consensus about the relationship between psychological contract and the other variables in this study, the relationship between AOC and job performance is not conclusive. The complexity of these two phenomena is an explanation for this gap in research on organizational behavior.

Job performance can be investigated as in-role or extra-role performance and assessed by many different methods, for example, self-ratings, supervisor ratings, or objective indicators. There is not broad consensus about the dimensionality of the job performance construct. It is a very complex construct and subject to important biases. In a meta-analysis, Riketta (2002) found that the correlation was significantly stronger for extra-role performance than for in-role performance as well as for performance assessed by self-ratings than for supervisor ratings or objective indicators. 
A review of the literature on commitment shows the existence of different perspectives: onedimensional views (Mowday et al., 1982; Solinger, Van Olffen, Roe, \& Hofmans, 2013) and multidimensional views (Meyer, Allen, \& Smith, 1993), person-centered approach (Meyer \& Morin, 2016), attitudinal views (Mowday et al., 1982; Solinger et al., 2013) and behavioral views (Staw, 1974) that focus on different targets of commitment, such as the organization, the job itself, the team, the career, and the labor union. It seems important to consider which one is the target of commitment in each case. Bishop and Scott (1997) found that team commitment led to increased productivity, but organizational commitment did not. Becker, Kernan, Clark and Klein (2015) found organizational commitment unrelated to productivity. No significant relationship between organizational commitment and job performance was found in other studies as well (Keller, 1997). The findings of Mathieu and Zajac (1990) suggest that commitment has relatively little effect on performance. On the other hand, Tolentino (2013) found AOC correlated significantly with job performance among the academic personnel in her research. Meyer, Stanley, Herscovitch and Topolnytsky's (2002) meta-analysis found that AOC positively correlated with job performance.

A review of previous studies relating the three constructs shows that, though they have a long tradition of research, they are typically studied separately. One reason for this may be the complexity of the phenomena involved. The job performance construct in particular is of high complexity and subjectivity and extremely vulnerable to many types of bias.

Our second hypothesis investigates the direct effects of psychological contract fulfillment and AOC on job performance, with no mediation between the variables. In this model, there is no link between psychological contract fulfillment and AOC, as shown in Figure 2.

Hypothesis 2: Psychological contract fulfillment and affective organizational commitment have direct effects on job performance.

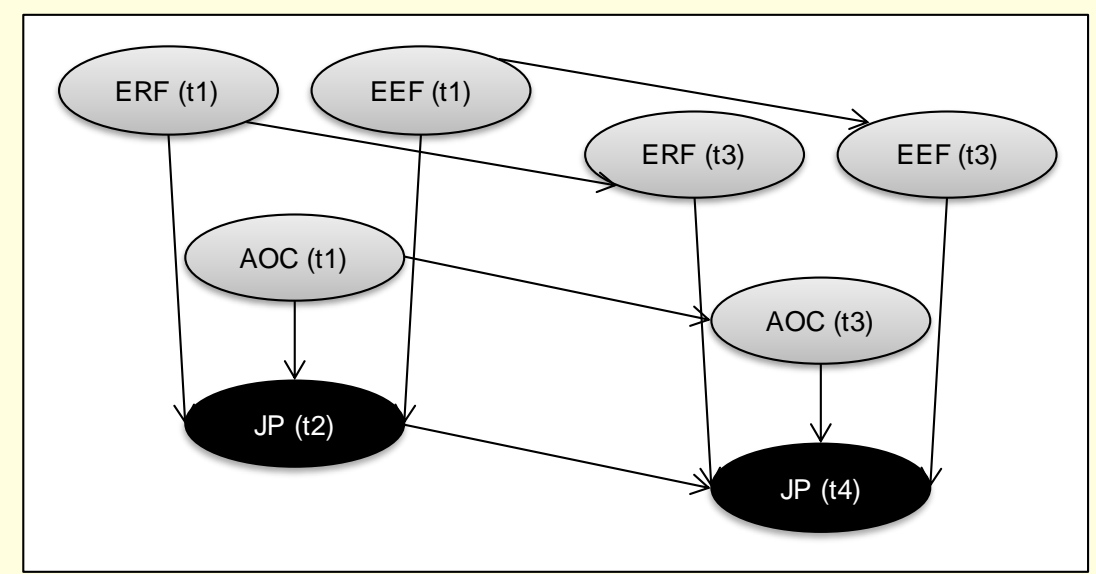

Figure 2. No mediation

Note. $\mathrm{ERF}=$ Employer Obligations Fulfillment; $\mathrm{EEF}=$ Employee Obligations Fulfillment; $\mathrm{AOC}=$ Affective Organizational Commitment; JP = Job Performance; "t" before a number indicates "Time" (e.g., t1 = Time1). 
In some studies, commitment is studied along with other constructs (e.g., job satisfaction) to investigate the effects of overall job attitude on performance. Such studies have shown weak but statistically significant positive effects (Harrison, Newman, \& Roth, 2006; Maia, Bastos, \& Solinger, 2016; Riketta, 2008). Fabi, Lacoursière and Raymond (2015) highlighted the mediating role played by job satisfaction and organizational commitment. Studies that investigated the three constructs were mostly cross-sectional in nature, which limits the ability to make causal inferences. The results of the only longitudinal study that was found suggest that perceived breaches of psychological contracts are most strongly associated with lower organizational commitment and job performance (Bunderson, 2001). Lester et al. (2002) found that the greater the psychological contract breach, the lower the AOC and job performance. Similar to the present study, Restubog, Bordia and Tang (2006) investigated the mediating role of AOC in the relationship between psychological contract breach and performance. They found that AOC mediates the relationship between psychological contract breach and extra-role performance. Hence, it is plausible that AOC may mediate the relationship between fulfillment of the psychological contract and job performance (in-role). Restubog et al. (2006) did not find that AOC mediates the relationship between breaches of psychological contracts and in-role performance. As previously mentioned, previous studies have shown that these relationships are stronger for extra-role performance than for in-role performance and performance assessed by self-ratings than for supervisor ratings or objective indicators (Riketta, 2002). The importance of in-role performance for the results of the organization makes it worthwhile to investigate.

Our third hypothesis is that when employees feel that their psychological contracts have been fulfilled by the employer, they will perform better and become more committed to the organization, which will make them perform even better. Our third hypothesis investigates the direct effects of fulfillment of the psychological contract on AOC, the direct and indirect effects of it on job performance, and the direct effects of AOC on job performance. In this model, all variables are interconnected, as shown in Figure 3.

Hypothesis 3: Affective organizational commitment partially mediates the relationship between fulfillment of the psychological contract and job performance.

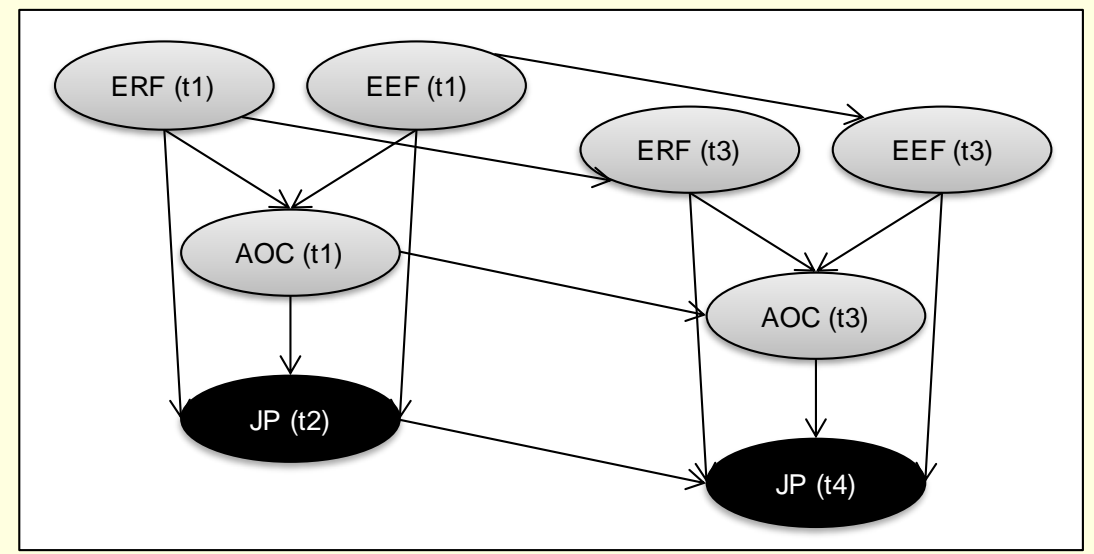

Figure 3. Partial mediation

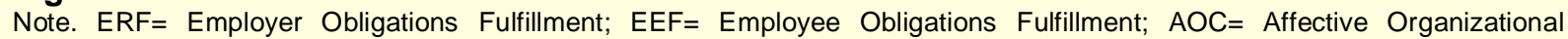
Commitment; JP= Job Performance; "t" before a number indicates "Time" (e.g., t1 = Time1). 


\section{Method}

\section{Sample and procedure}

The study's plan was submitted to, and approved by, a research ethics committee. The study's population consists of 361 individuals who passed a competitive selection process to select civil servants for a government agency. The newcomers received an e-mail invitation to answer a questionnaire approximately one year ( $\mathrm{t} 1 \mathrm{l})$ and three years after entry ( $\mathrm{t} 3$ ). Job performance was evaluated by their bosses about two months after each measure ( $\mathrm{t} 2$ and $\mathrm{t} 4$ ). We adopted two techniques for controlling common method bias: by obtaining measures of the predictor and criterion variables from different sources, and by introducing a time lag between the measurement of the predictor and criterion variables (Podsakoff, Mackenzie, Lee, \& Podsakoff, 2003).

In the invitation e-mail, we explained the study, and there was an external link to the questionnaire. The text reinforced the facts that it was a survey independent from the organization's human resources department and that it was being done under academic supervision, with identification of the researchers. Participation in the study was voluntary, and confidentiality was formally guaranteed. We used a survey platform that generated a different link for each e-mail message, thus allowing the identification of respondents, which made it possible to merge the results of different surveys over time, and these results with the performance appraisals. Respondents did not have access to the answers of previous collections. After data collection, respondents were coded into numbers.

The first survey was filled out by 251 individuals, and 202 participated in both surveys (56\% response rating). Twenty-four employees left the organization (eight percent) during the study, three were temporarily transferred to another public agency, and one died. Analyses concerning change were conducted using the data from those who answered all surveys. The mean age of respondents was 36 years $(\mathrm{SD}=7.5), 26.7 \%$ were female, all respondents had at least a university degree, and $66 \%$ had completed some type of postgraduate program. To investigate the possibility of bias produced by the reduction of the sample, several analyses were conducted. Comparison of the participants in the full study and those who left at some point did not produce any significant detectable differences in the demographic characteristics or outlying responses in the sample. The conclusion was that the reduction of the sample over time did not seem to create any bias in the variables of this study.

\section{Research context}

This research was done in a Brazilian autonomous federal government agency that has approximately 4,000 employees. The organizational context is one of job security, as long-term employment is guaranteed by the agency, turnover is low, and the performance-pay link is limited. In the job market, the agency offers comparatively high salaries. The newcomers were selected for analyst positions, working in the areas of economics, management, accounting, finance, and 
information technology. Only after approval and entry into the organization was the newcomer informed of which department of the organization s/he would work in and what his/her activities would be. The evaluation of institutional performance in the Brazilian public sector was defined by Law $11784 / 2008$, to be composed of criteria and factors that reflected the competencies of the employees assessed for the performance of individual tasks and activities assigned to them, the contribution of the team working to fulfill the intermediate and overall targets of the agency, and the results achieved by the organization as a whole (Lei n. 11.784, 2008). The last decades of the twentieth century saw the development of performance appraisal techniques across multiple appraisers, the trend toward integration of individual and team performance, and the rise of the concept of performance evaluation tied to skills development. Even with such advances, performance measurement in the context of Brazilian public administration remains a challenge that requires further study.

\section{Measures}

We assessed fulfillment of the psychological contract (predictive variable) and affective organizational commitment (predictive and dependent variable) at $\mathrm{t} 1$, and two months later, job performance (dependent variable) was evaluated by the supervisors of each employee at $t 2$. Two years later, we repeated the same process, at $\mathrm{t} 3$ and $\mathrm{t} 4$.

Fulfillment of the psychological contract was calibrated with the measure by Maia (2014). The Psychological Contract Instrument consists of two scales, the Employee obligations and the Employer obligations. We assessed the fulfillment of employer and employee obligations at $\mathrm{t} 1$ and $\mathrm{t} 3$. The respondents were asked to rate how much they believed that their employer had fulfilled the obligations towards them and how much they believed they had fulfilled their obligations towards the employer, on a Likert scale ranging from $1=$ not at all to $5=$ totally fulfilled.

Affective organizational commitment was operationalized using an instrument by Maia (2014), composed of four items from the OCQ (Organizational Commitment Questionnaire; Mowday, Steers, \& Porter, 1979) and three items from the ACS (Affective Commitment Scale; Meyer et al., 1993). The items from the OCQ are: This organization really inspires the very best in me in the way of job performance; I find that my values and the organization's values are very similar; I pitch this organization to my friends as a great place to work; and I am proud to tell others that I am part of this organization. The items from the ACS are: I really feel as if this organization's problems are my own; This organization has a great deal of personal meaning for me; I feel emotionally attached to this organization. AOC was assessed at $\mathrm{t} 1$ and $\mathrm{t} 3$ using a Likert Scale ranging from $1=$ strongly disagree to $5=$ strongly agree.

We assessed job performance by supervisor ratings in performance appraisals undertaken by the organization. We obtained indicators on five criteria: assiduity, discipline, sense of initiative, productivity, and responsibility. Job performance was assessed at t 2 and t 4 on a Likert Scale ranging from 1 = far below the minimum standards expected to $4=$ excellent in relation to expected standards. 
First, exploring the data with SPSS 22.0, we analyzed descriptive statistics, regression weights, and performed exploratory factor analyses. All measures showed acceptable reliabilities over time; Cronbach's alphas ranged from 0.77 to 0.96 . In order to assess construct validity, we carried out confirmatory factor analyses on the data with AMOS 21.

The model indicated a good fit for the AOC Scale at $\mathrm{t} 1$ and $\mathrm{t} 3$ (e.g., goodness-of-fit index - GFI: 0.953, 0.963; Root-mean-square residual - RMR: 0.039, 0.036, respectively), for the Scale of Employer Obligations Fulfillment (e.g., GFI: 0.919, 0.926; RMR: 0.051, 0.036, respectively), and for the Scale of Employee Obligations Fulfillment (e.g., GFI: 0.948, 0.948; RMR: 0.026, 0.020, respectively). The model also indicated a good fit for the measure of job performance at $\mathrm{t} 2$ and t4 (e.g., GFI: 0.993, 0.986; RMR: 0.001, 0.003, respectively). The complete model indicated a satisfactory fit, as shown in the results section of this article.

\section{Structural equation modeling analysis}

We applied structural equation modeling with SPSS 22.0 and IBM SPSS Amos 21.0. We used SPSS 22.0 to explore the effect of one variable over another, and we used Amos Version 21 to identify how much such variables were related, the proportion of relationship between the variables, by applying structural equation modeling (SEM), also known as analysis of covariance structures, or causal modeling. In all analyses, we used the maximum likelihood (ML) estimation method. The data failed to perfectly meet the assumption of multivariate normality that the ML estimation is based on. Deviations from normality were moderate and only involved some of the self-reported variables, but we additionally performed bootstrapping with a percentile confidence and bias-corrected confidence of 95 . To analyze the hypotheses, we initially analyzed $t 1$ and $t 2$, t3 and t4 separately. All measurements were then integrated, and the three models were compared. The first model is the total mediation, i.e., there is no direct link between the psychological contract and job performance. In the second model, fulfillment of the psychological contract and AOC affect job performance independently. In this model, there is no link between fulfillment of the psychological contract and AOC. The third model verifies the hypothesis that AOC partially mediates the relationship between fulfillment of the psychological contract and job performance. We compared the goodness-of-fit indices for these alternative models. Satisfactory model fit was indicated when the proportion of chi-square to degrees of freedom $\left(\chi^{2} / \mathrm{df}\right)$ was less than 3 , root mean-square error of approximation (RMSEA) was less than 0.08, standardized root mean-square (SRMR) was less than 0.10 , and goodness-of-fit index (GFI), adjusted GFI (AGFI), normed fit index (NFI), and comparative fit index (CFI) were greater than 0.90 (Schumacker \& Lomax, 2010). 


\section{Results}

\section{Fulfillment of the psychological contract and AOC}

The correlations between fulfillment of the psychological contract (employer and employee obligations) and AOC were all significant at the .001 level and ranged from 0.298 to 0.551 , as shown in Table 1, which reports descriptive statistics, correlations, and Cronbach's alphas for all scales. The correlations with employee obligations fulfillment were smaller than the correlations with employer obligations fulfillment.

The regression weights between fulfillment of the psychological contract (employer and employee obligations) and AOC were all significant at the .001 level. The regression weights between employee obligations fulfillment and $\mathrm{AOC}$ were 0.230 at $\mathrm{t} 1$ and 0.196 at $\mathrm{t} 3$. The relationship between employer obligations fulfillment and $\mathrm{AOC}$ is strong, with regression weights greater than 0.50 , i.e., they were 0.514 at $\mathrm{t} 1$ and 0.547 at $\mathrm{t} 3$.

The fulfillment of the psychological contract explained $39.7 \%$ of the variation of AOC at $\mathrm{t} 1$ and $42.4 \%$ at $t 3$. The predictive power of the variables of fulfillment of the psychological contract in relation to AOC proved to be strong and significant. 
Table 1

Means, standard deviations (SD), correlations, and Cronbach's alphas for the study's variables

\begin{tabular}{|c|c|c|c|c|c|c|c|c|c|c|}
\hline Variable & Mean & SD & 1 & 2 & 3 & 4 & 5 & 6 & 7 & 8 \\
\hline 1. ERF (t1) & 2.77 & 0.66 & $(.86)$ & & & & & & & \\
\hline 2. EEF (t1) & 3.49 & 0.43 & $.239^{* *}$ & $(.77)$ & & & & & & \\
\hline 3. $\mathrm{AOC}(\mathrm{t} 1)$ & 4.11 & 0.80 & $.537^{\star *}$ & $.298^{\star *}$ & (.89) & & & & & \\
\hline 4. JP (t2) & 3.50 & 0.42 & .110 & $.167^{\star}$ & .002 & $(.96)$ & & & & \\
\hline 5. ERF (t3) & 2.85 & 0.68 & $.624^{\star *}$ & $.178^{*}$ & $.363^{* *}$ & $.126+$ & $(.88)$ & & & \\
\hline 6. EEF (t3) & 3.54 & 0.48 & $.181^{*}$ & $.584^{\star *}$ & $.275^{\star *}$ & $.195^{\star *}$ & $.294^{\star *}$ & $(.80)$ & & \\
\hline 7. $\mathrm{AOC}(\mathrm{t} 3)$ & 3.81 & 0.82 & $.474^{* *}$ & $.286^{\star *}$ & $.745^{\star *}$ & -.072 & $.551^{* *}$ & $.333^{\star *}$ & (.89) & \\
\hline 8. JP (t4) & 3.54 & 0.40 & .094 & .114 & .011 & $.301^{* *}$ & $.177^{*}$ & $.140^{*}$ & .034 & $(.95)$ \\
\hline
\end{tabular}

Note. $\mathrm{N}=202$. ERF= Employer Obligations Fulfillment; $\mathrm{EEF}=\mathrm{Employee}$ Obligations Fulfillment; $\mathrm{AOC}=\mathrm{Affective}$ Organizational Commitment; JP= Job Performance; "t" before a number indicates "Time" (e.g., $\mathrm{t} 1=\mathrm{Time1}$ ). ERF, EEF, and AOC are expressed on a 5-point scale. JP is expressed on a 4-point scale. Cronbach's alphas for scales appear on the diagonal parentheses. $+p<.10 .{ }^{*} p<.05$. ${ }^{* *} \mathrm{p}<.01$. 


\section{Fulfillment of the psychological contract and job performance}

The correlations between psychological contract fulfillment and job performance were all significant at the .05 level, except for employer obligations fulfillment and job performance ( $t 1$ and $\mathrm{t} 2$ ). The correlations ranged from 0.110 to 0.177 , as shown in Table 1.

Consistently, the regression weight between employer obligations fulfillment and job performance was not significant in the analyses of the first measures ( $t 1$ and $t 2)$, but it was significant at $\mathrm{t} 3$ and $\mathrm{t} 4\left(\mathrm{r}^{2}=0.141, \mathrm{p}<.05\right)$. Differently, for employee obligations fulfillment and job performance, it was significant at $\mathrm{t} 1$ and $\mathrm{t} 2\left(\mathrm{r}^{2}=0.194, \mathrm{p}<.01\right)$ and was not significant at $\mathrm{t} 3$ and $\mathrm{t} 4$.

The fulfillment of the psychological contract explained $5.1 \%$ of the variation of job performance at $\mathrm{t} 2$ and $5.2 \%$ at $\mathrm{t} 4$. The predictive power of the variables of fulfillment of psychological contract in relation to $\mathrm{AOC}$ cannot be dismissed.

\section{AOC and job performance}

The correlations between $\mathrm{AOC}$ and job performance were not significant and approached 0 $(0.002 ; 0.011 ;-0.072 ; 0.034)$, as shown in Table 1 . The regression weights between AOC and job performance in all analyses were not significant and close to 0 . We did not find a relationship between AOC and job performance. Coherent with the correlations and regressions weights, AOC did not explain variation of job performance.

\section{Three models to be tested}

We then integrated the measures of the psychological contract (i.e., fulfillment of employer and employee obligations) and AOC, and the global measure of performance over time, in the models to be tested. Table 2 reports the direct and indirect standardized regression weights between the variables of psychological contract fulfillment (employer and employee obligations) with and without AOC in the model in order to evaluate its mediating effect. The direct beta without the AOC mediator shows whether there is a relationship between the variables of psychological contract fulfillment and job performance. As previously reported in the analysis of descriptive statistics, the relationship between psychological contract fulfillment and job performance was not significant in all analyses. Neither the fulfillment of the psychological contract nor AOC proved to have a predictive significant power in relation to job performance in all analyses. However, with these constructs together in an explanatory model, the explanatory power of the variables of psychological contract fulfillment increased and became significant at all times, ranging from 0.163 to 0.238 . 
Table 2

Mediation models: AOC as mediator

\begin{tabular}{llllllc}
\hline & \multicolumn{2}{c}{ Indirect beta } & \multicolumn{2}{c}{ Direct beta without mediator } & \multicolumn{2}{c}{ Direct beta with mediator } \\
\cline { 2 - 8 } & $(\mathrm{t} 1)$ & $(\mathrm{t})$ & $(\mathrm{t} 1)$ & $(\mathrm{t} 3)$ & $(\mathrm{t})$ & $(\mathrm{t})$ \\
\hline $\mathrm{JP} \leftarrow$ ERF & $-.099^{*}$ & $-.092^{*}$ & $.068 \mathrm{~ns}$ & $.141^{*}$ & $.167^{*}$ & $.232^{* *}$ \\
$\mathrm{JP} \leftarrow$ EEF & $-.044^{* *}$ & $-.033^{*}$ & $.194^{* *}$ & $.130+$ & $.238^{* *}$ & $.163^{*}$ \\
\hline
\end{tabular}

Note. $\mathrm{N}=202$. $\mathrm{ERF}=$ Employer Obligations Fulfillment; $\mathrm{EEF}=$ Employee Obligations Fulfillment; $\mathrm{AOC}=\mathrm{Affective}$ Organizational Commitment; JP = Job Performance. Two-tailed significance. $+p<.10 .{ }^{*} p<.05 .{ }^{* *} p<.01$.

Considering that both the direct beta and indirect effects from psychological contract fulfillment on job performance with AOC as mediator were significant, we can say that there is a mediation relationship between the variables, thus supporting hypotheses 1 and 3. Hypothesis 2 is partially supported since fulfillment of the psychological contract proved to have effects on job performance in part of the results. Even so, it is important to note that, on their own, the variables of psychological contract showed no consistency in the results relating to job performance, and AOC alone had no explanatory power in relation to job performance. The second model, of no mediation, seems not to be the best model considering the results shown in Tables 1 and 2 .

Considering that the indirect effect was significant and that the direct effects did not drop out of significance when we added the mediator, the hypothesis of full mediation can be discarded. The exact opposite happened, i.e., instead of a drop out of significance, they improved. Notice that the signs of the direct and indirect coefficients are opposite. This pattern of coefficients is known as inconsistent mediation. In such cases, where the direct and mediated effects of an independent variable on a dependent variable have opposite signs, a suppression effect is present (Tzelgov \& Henik, 1991). A suppression effect can be observed when a variable is not correlated with the dependent variable and strongly correlated with other predictors. The indirect effect with a sign different from its validity indicates that the employer and employee obligations fulfillment were suppressed by AOC within the mediation model. A suppression effect can be observed when a variable is not correlated with the dependent variable and strongly correlated with other predictors (Tzelgov \& Henik, 1991). AOC thus becomes a classic suppressor variable that improves prediction by virtue of being highly correlated with fulfillment of employer and employee obligations. The fit for each model is shown in Table 3.

Table 3

\section{Goodness-of-fit indices for alternative models}

\begin{tabular}{lccccccccc}
\hline Model tested & $\chi 2$ & $\mathrm{df}$ & $\mathrm{p}$ & RMSEA & SRMR & GFI & AGFI & NFI & CFI \\
\hline H1: Full mediation & 50.869 & 16 & .000 & .104 & .074 & .942 & .870 & .951 & .965 \\
H2: No mediation & 226.508 & 16 & .000 & .256 & .239 & .825 & .607 & .780 & .790 \\
H3: Partial Mediation & 27.449 & 12 & .007 & .080 & .017 & .970 & .911 & .973 & .985 \\
Independence model & 1028.880 & 28 & .000 & .422 & - & .465 & .312 & .000 & .000 \\
\hline
\end{tabular}

Note. $\mathrm{N}=202$. 
The goodness-of-fit indices leave no doubt that the model that best fits the data is the one of partial mediation. It was the only model in which the ratio $\chi^{2} / \mathrm{df}$ was less than 3 , the value of RMSEA was acceptable, and AGFI was greater than 0.90. The chi-square difference test also confirmed that the mediation model had the best fit to data; hence, hypothesis 3 is fully supported.

\section{Partial mediation model}

As we mentioned in sections "Fulfillment of the psychological contract and job performance" and "AOC and job performance", respectively, the fulfillment of psychological contract explained about $5 \%$ of the variance in job performance at $\mathrm{t} 2$ and $\mathrm{t} 4$, and $\mathrm{AOC}$ had no explanatory power in relation to performance. Together in a mediation model, psychological contract fulfillment and $\mathrm{AOC}$ explained $7.4 \%$ of the variance in job performance at $\mathrm{t} 2$ and $6.8 \%$ at $\mathrm{t} 4$, as shown in Figure 4.

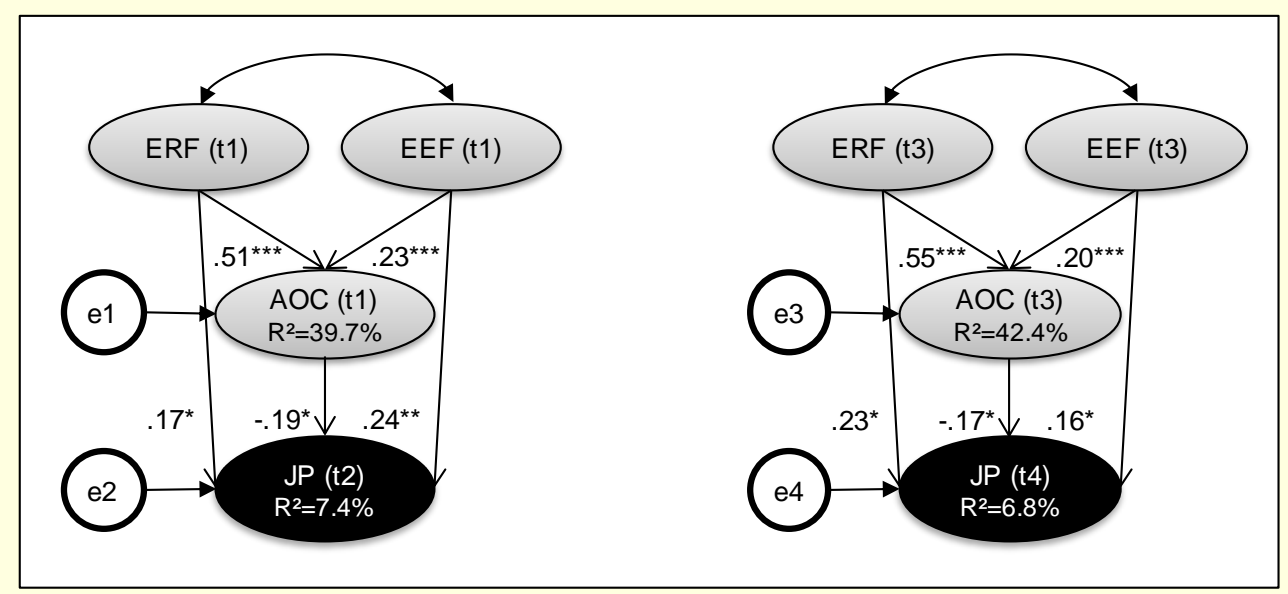

Figure 4. Partial mediation model

Note. $\mathrm{N}=202$. $E R F=$ Employer Obligations Fulfillment; EEF= Employee Obligations Fulfillment; $A O C=$ Affective Organizational Commitment; JP= Job Performance. Standardized regression weights are reported. Two-tailed significance. $n s=$ non-significant, $+p<.10,{ }^{*} p<.05,{ }^{* *} p<.01,{ }^{* * *} p<.001$.

As can be seen in Figure 4, the regression weights between AOC and job performance are significant and negative for $\mathrm{t} 2$ and $\mathrm{t} 4$. According to Maassen and Bakker (2001, p. 242), "this reflects the fact that the irrelevant elements from the predictor are partialed out, which 'purifies' the predictor and improves the prediction". This is the expected behavior of a suppressor variable, when it is positively correlated with the predictor. This does not mean, however, that AOC has a negative relationship with performance. We need to recall that our findings in this study suggests that AOC has no predictive power with respect to job performance. There is no positive relationship, nor a negative one. Nevertheless, it can improve the way fulfillment of the psychological contract explains the dependent variable. The addition of AOC to the model as a mediating variable increased the explanatory power regarding the variance in job performance by $2.3 \%$ at $\mathrm{t} 2$ and $1.6 \%$ at $\mathrm{t} 4$. It is a small increase in explanatory power, but the relationships were significant in all analyses. 
AOC proved to work as a classical suppressor variable, which refers to "a variable which increases the predictive validity of another variable (or set of variables) by its inclusion in a regression equation" (Conger, 1974, p. 36). A suppressor variable works like a cleansing agent for the variance of the predictor variables by suppressing the irrelevant information within the predictors. If a variable is revealed a suppressor in a model, and "a path coefficient between this variable and the dependent variable has been found with a sign opposite to that hypothesized, one should not conclude that a direct effect contrary to that expected is operating" (Maassen \& Bakker, 2001, p. 268). The sign of the coefficient of AOC switches in combination with the explanatory variables of fulfillment of the psychological contract. It does not make sense to interpret the coefficient of AOC as a direct effect in the strict sense (Maassen \& Bakker, 2001). The interpretation of the effects should be combined, and the resulting composite from the whole model may be meaningful. The final model integrated the measures over time and are shown in Figure 5. In the complete longitudinal partial mediation model, job performance had $12.3 \%$ of the variance explained at $t 4$. The results suggest that AOC can improve the way fulfillment of the psychological contract explains the dependent variable. Notice that the effects of the second measure of each variable are mediated by the first measure, but even so the effects of employer obligations fulfillment remains significant. AOC at $\mathrm{t} 3 \mathrm{had} 86.3 \%$ of the variance explained, and job performance at $\mathrm{t} 4 \mathrm{had} 12.3 \%$ of the variance explained.

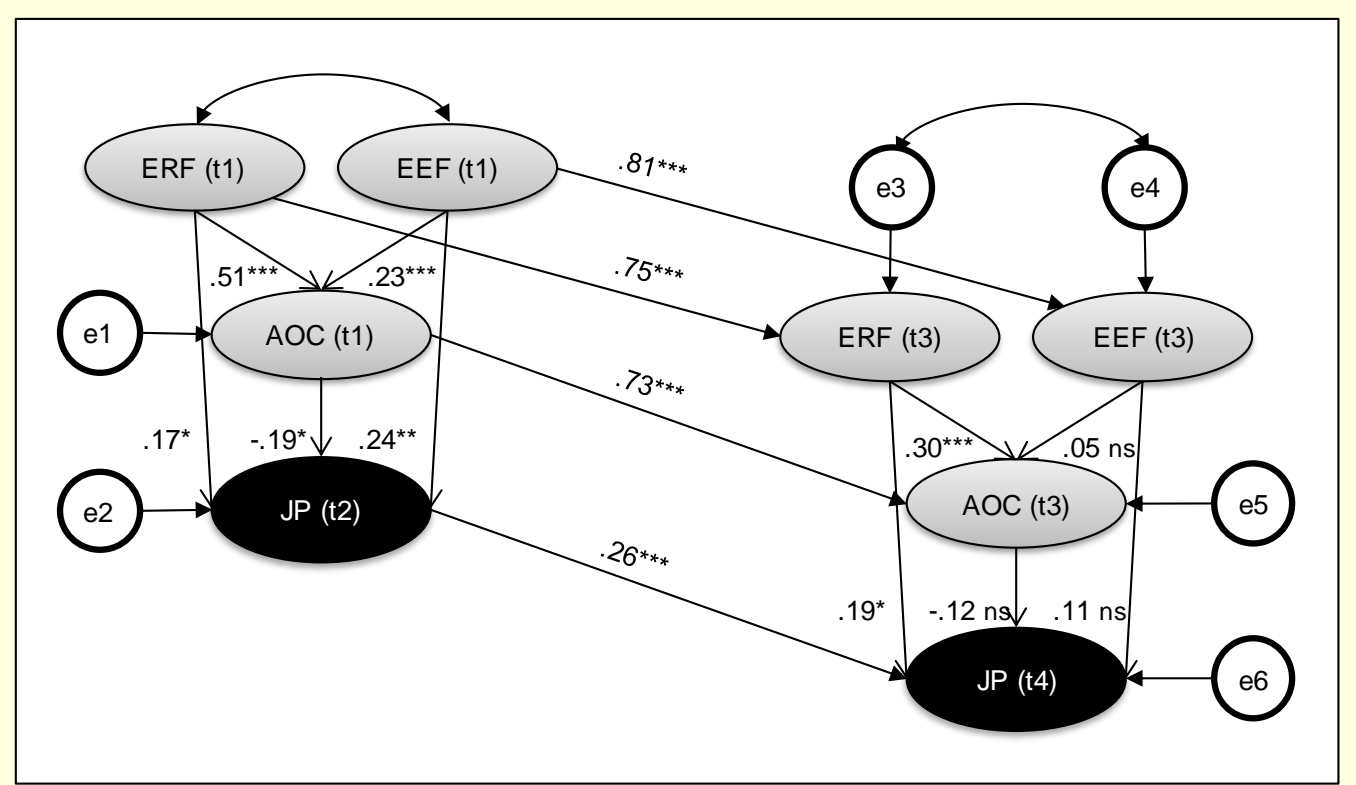

Figure 5. Partial mediation model results

Note. $\mathrm{N}=202$. $\mathrm{ERF}=$ Employer Obligations Fulfillment; $E E F=$ Employee Obligations Fulfillment; $A O C=$ Affective Organizational Commitment; $\mathrm{JP}=$ Job Performance. Standardized regression weights are reported. Two-tailed significance. $n s=$ non-significant, $+p<.10,{ }^{*} p<.05,{ }^{* *} p<.01,{ }^{* * *} p<.001$. 


\section{Discussion}

Considering this research design, with multiple sources and a time lag between the measurement of the predictor and criterion variables, having $12.3 \%$ of the variance explained for a construct like job performance - of high complexity and subjectivity and extremely vulnerable to many types of bias - is a notable result. It is easier to have high variance explained with the same individuals answering a survey with predictor and criterion variables at the same time, due to common method bias, than to have it answered by different sources with a time lag between predictor and criterion variables, and it is even much easier if the study is cross-sectional rather than longitudinal. The multidimensionality of job performance makes it an extremely complex research topic. Apart from individual differences and the willingness to perform, there are external factors outside the control of the individual involved in his/her job performance, such as organizational support, clarity of roles (which reduces the ambiguity or conflict), and competitiveness within the organization.

The results of this study support the idea that the relationship between psychological contract fulfillment and AOC is positive, as previous research has shown (McInnis et al., 2009). This means that when employees feel that their psychological contracts have been fulfilled by the employer and by themselves, they become more committed to the organization. These findings show that psychological contract fulfillment has considerable explanatory power in relation to AOC. Furthermore, the results suggest that psychological contract fulfillment is positively related to job performance, in agreement with findings of other studies (Conway \& Coyle-Shapiro, 2011; Turnley, Bolino, Lester, \& Bloodgood, 2003). That is, when employees perceive that their psychological contracts have been fulfilled by the employer and by themselves, they perform better. On their own, the variables of psychological contract fulfillment explain about $5 \%$ of the variance in the job performance variable. In an analysis including AOC, the explanatory power increases.

The relationship between AOC and job performance proved to be insignificant both in correlational terms and in terms of regression weights. Accordingly, the results for the effects of AOC on job performance are not conclusive in the literature. The results revealed here suggest that AOC has a mediation effect on the relationship between fulfillment of the psychological contract and job performance. AOC represents a generative mechanism through which the fulfillment of the psychological contract is able to predict job performance. The results showed that when employees feel that their psychological contracts have been fulfilled, they become more affectively committed to the organization, and that when employees feel that their psychological contracts have been fulfilled, they perform better. Notice that, given the results, there is a missing link in this model. One cannot say that when employees are more affectively committed to the organization, they perform better. There is no such direct relationship; however, there are observable effects of the level of AOC. One of the goals of this study is to facilitate the understanding of how these effects occur (albeit indirectly).

A metaphor may help us to understand these results. Books on top of a bookcase represent the best job performances. The steps of a ladder represent all the numerous predictors of job 
performance. This ladder is necessary to reach the books at the top. However, the results show that AOC is not conducive to achieving better performance. Thus, it is not a step on the ladder, while the fulfillment of the psychological contract is. In this metaphor, AOC would be the difference in how much an individual who tries to reach books on top of the bookcase can stretch his/her arms. Note that a ladder is essential for everyone, regardless of arm length. The length of the arms and how far they can be stretched make the difference between two people with a ladder of the same height (i.e., similar levels of fulfillment of psychological contract), so that one person can reach books that another person cannot.

Within this metaphor, for the model that considers only the variables of psychological contract and job performance, we would have measured the height of the ladder. In the model that considers the three constructs, we would have measured the total height achieved, taking into account how much each person can stretch his/her arms. Arm length provides a better estimate of the height of the book reached (i.e., greater explanatory power in relation to job performance), but only by means of the ladder (i.e., fulfillment of the psychological contract). Therefore, the difference due to different levels of AOC must be discounted, and for the same reason, the signs of regression weights are negative. To understand the relationship between fulfillment of the psychological contract and job performance, we have to eliminate the effect that respondents may perform well only because of their level of AOC. In this analysis, it is important to remember that, unlike the psychological contract and AOC, which express a set of beliefs and attitudes, job performance expresses a set of behaviors. Within the metaphor, the individual may be fully able to reach the book on top with the ladder at hand, but the act of climbing does not occur.

\section{Conclusion}

This study's results show a strong link between psychological contract fulfillment, AOC, and job performance. This indicates that the manager can expect the employee to commit more or less to the organization and perform better or worse depending on the level to which the organization fulfills its obligations in the psychological contract. These findings highlight the importance of psychological contract management and of the expectations created even before entering the organization. This includes the initial experience in recruiting, the selection processes, and the initial socialization periods to provide newcomers with accurate information regarding their jobs in an attempt to avoid potential unmet pre-entry expectations and breaches in the psychological contract that result from misunderstandings. Therefore, it is crucially important for companies to avoid creating false hopes during the selection stages of recruitment. Once employees are hired, during the early socialization process, organizations should strive to get to know the employees, fulfill their promises, balance their psychological contracts, maintain their AOC levels, and try to improve job performance. These findings provide a way to better understand the consequences that may result from a failure to communicate what is expected of an employee or a failure to listen to what the employee expected from the employer.

This study advances prior research by suggesting that job performance might be better predicted by a combination of variables, such as in the case of this study. The results of this study show how the variables of fulfillment of the psychological contract, considering both the obligations of 
the employer and the employee, explain job performance, and that the inclusion of organizational commitment as a mediating variable increased the explanatory power of the psychological contract.

The results of this study also provide insights that may be useful for the practice of performance management in organizations. First, the organization should identify the relevant performance behaviors for better organizational performance. Second, the organization should try to find mechanisms to favor such behaviors. Third, these behaviors should be recognized and valued so that they are stimulated. Finally, it is important to keep lines of communication open so that in cases of dissatisfaction, individuals can communicate rather than simply leave the organization or passively wait for improved conditions. It is essential that individuals perceive themselves as able to communicate and seek better conditions to achieve high performance. After all, using our metaphor, if it there is no available ladder, employees may give up on stretching their arms unsuccessfully.

\section{Acknowledgments}

We are grateful to the reviewers whose constructive comments strengthened this paper. This work was supported by the Coordination for the Improvement of Higher Education Personnel (CAPES), under grant 9480/12-9. This work was also supported by the National Council for Scientific and Technological Development (CNPq) under grant 476160/2011-1.

The views expressed in this paper are those of the authors and do not necessarily reflect the views of the Central Bank of Brazil.

\section{Contributions}

Both authors have participated actively in the discussion of results and in the final revision of the paper. The first author was a $\mathrm{PhD}$ candidate by the time the study was done, and the second author was the $\mathrm{PhD}$ supervisor.

\section{References}

Bal, P. M., Chiaburu, D. S., \& Jansen, P. G. W. (2010). Psychological contract breach and work performance: Is social exchange a buffer or an intensifier? Journal of Managerial Psychology, 25(3), 252-273. https://doi.org/10.1108/02683941011023730

Becker, T. E., Kernan, M. C., Clark, K. D., \& Klein, H. J. (2015). Dual commitments to organizations and professions different motivational pathways to productivity. Journal of Management, 44(3), 1202-1225. https://doi.org/10.1177/0149206315602532

Bishop, J. W., \& Scott, D. (1997). How commitment affects team performance. HR Magazine, 42(2), $107-111$. Retrieved from https://works.bepress.com/dow_scott/42/ 
Borman, W., \& Motowidlo, S. (1993). Expanding the criterion domain to include elements of contextual performance. In N. Schmitt \& W. C. Borman (Eds.), Personnel selection in organizations (pp. 71-98). San Francisco, CA: Jossey-Bass.

Bunderson, J. S. (2001). How work ideologies shape the psychological contracts of professional employees: doctors' responses perceived breach. Journal of Organizational Behavior, 22(7), 717-741. https://doi.org/10.1002/job.112

Campbell, J. P. (1999). The definition and measurement of performance in the new age. In D. R. Ilgen \& E. D. Pulakos (Eds.), The changing nature of performance (pp. 399-429). San Francisco, CA: Jossey-Bass.

Conger, A. J. (1974). A revised definition for suppressor variables: A guide to their identification and interpretation. Educational Psychological Measurement, 34(1), 35-46. https://doi.org/10.1177/001316447403400105

Conway, N., \& Briner, R. B. (2005). Understanding psychological contracts at work: A critical evaluation of theory and research. Oxford: Oxford University.

Conway, N., \& Coyle-Shapiro, J. A. M. (2011). The reciprocal relationship between fulfilment of the psychological contract and employee performance and the moderating role of perceived organizational support and tenure. Journal of Occupational and Organizational Psychology, 85(2), 277-299. https://doi.org/10.1111/j.20448325.2011.02033.x

Fabi, B., Lacoursière, R., \& Raymond, L. (2015). Impact of high-performance work systems on job satisfaction, organizational commitment, and intention to quit in Canadian organizations. International Journal of Manpower, 36(5), 772-790. https://doi.org/10.1108/ijm-01-2014-0005

Harrison, D. A., Newman, D. A., \& Roth, P. L. (2006). How important are job attitudes? Meta-analytic comparisons of integrative behavioral outcomes and time sequences. The Academy of Management Journal, 49(2), 305-325. https://doi.org/10.5465/amj.2006.20786077

Johnson, J. L., \& O'Leary-Kelly, A. M. (2003). The effects of psychological contract breach and organizational cynicism: Not all social exchange violations are created equal. Journal of Organizational Behavior, 24(5), 627-647. https://doi.org/10.1002/job.207

Keller, R. T. (1997). Job involvement and organizational commitment as longitudinal predictors of job performance: A study of scientists and engineers. Journal of Applied Psychology, 82(4), 539-545. https://doi.org/10.1037/0021. 9010.82.4.539

Lei n. 11.784, de 22 de setembro de 2008. (2008). Dispõe sobre a reestruturação do Plano Geral de Cargos do Poder Executivo - PGPE, de que trata a Lei no 11.357, de 19 de outubro de 2006, ...; e dá outras providências. Retrieved from http://www.planalto.gov.br/ccivil_03/_ato2007-2010/2008/Lei/L11784.htm

Lester, S. W., Turnley, W. H., Bloodgood, J. M., \& Bolino, M. C. (2002). Not seeing eye to eye: Differences in supervisor and subordinate perceptions of and attributions for psychological contract breach. Journal of Organizational Behavior, 23(1), 39-56. https://doi.org/10.1002/job.126

Maassen, G. H., \& Bakker, A. B. (2001). Suppressor variables in path models: Definitions and interpretations. Sociological Methods $\mathcal{E}$ Research, 30(2), 241-270. https://doi.org/10.1177/0049124101030002004

Maia, L. G. (2014). Organizational commitment, psychological contract and job performance: A longitudinal study with newcomers (Tese de doutorado). Universidade Federal da Bahia, Salvador, BA, Brasil.

Maia, L. G., Bastos, A. V. B., \& Solinger, O. N. (2016). Which factors make the difference for explaining growth in newcomer organizational commitment? A latent growth modeling approach. Journal of Organizational Behavior, 37(4), 537-557. https://doi.org/10.1002/job.2096

Mathieu, J. E, \& Zajac, D. M. (1990). A review and meta-analysis of the antecedents, correlates and consequences of organizational commitment. Psychological Bulletin, 108(2), 171-194. https://doi.org/10.1037//0033. 2909.108.2.171

McInnis, K. J., Meyer, J. P., \& Feldman, S. (2009). Psychological contracts and their implications for commitment: A feature-based approach. Journal of Vocational Behavior, 74(2), 165-180. https://doi.org/10.1016/j.jvb.2008.12.007 
Meyer, J. P., Allen, N. J., \& Smith, C. A. (1993). Commitment to organizations and occupations: extension and test of a three component conceptualization. Journal of Applied Psychology, 78(4), 538-551. https://doi.org/10.1037//0021-9010.78.4.538

Meyer, J. P., \& Morin, A. J. S. (2016). A person centered approach to commitment research: Theory, research, and methodology. Journal of Organizational Behavior, 37(4), 584-612. https://doi.org/10.1002/job.2085

Meyer, J. P., Stanley, D. J., Herscovitch, L., \& Topolnytsky, L. (2002). Affective, continuance and normative commitment to the organization: A meta-analysis of antecedents, correlates, and consequences. Journal of Vocational Behavior, 61(1), 20-52. https://doi.org/10.1006/jvbe.2001.1842

Mowday, R. T., Porter, L. W., \& Steers, R. M. (1982). Employee-organization linkages: The psychology of commitment, absenteeism, and turnover. New York, NY: Academic Press.

Mowday, R. T., Steers, R. M., \& Porter, L. W. (1979). The measurement of organizational commitment. Journal of Vocational Behavior, 14, 224-247. https://doi.org/10.1016/0001-8791(79)90072-1

Podsakoff, P. M., Mackenzie, S. B., Lee, J.-Y., \& Podsakoff, N. P. (2003). Common method biases in behavioral research: A critical review of the literature and recommended remedies. Journal of Applied Psychology, 88(5), 879903. https://doi.org/10.1037/0021-9010.88.5.879

Restubog, S. L. D., Bordia, P., Krebs, S. A., \& Tang, R. L. (2005). The role of leader-member exchange in the psychological contract breach - subordinates' performance relationship. Academy of Management Proceedings, 1, I1-I6. https://doi.org/10.5465/ambpp.2005.18780579

Restubog, S. L. D., Bordia, P., \& Tang, R. L. (2006). Effects of psychological contract breach on performance of IT employees: The mediating role of affective commitment. Journal of Occupational and Organizational Psychology, 79(2), 299-306. https://doi.org/10.1348/096317905x53183

Riketta, M. (2002). Attitudinal organizational commitment and job performance: A meta-analysis. Journal of Organizational Behavior, 23(3), 257-266. https://doi.org/10.1002/job.141

Riketta, M. (2008). The causal relation between job attitudes and performance: A meta-analysis of panel studies. Journal of Applied Psychology, 93(2), 472-481. https://doi.org/10.1037/0021-9010.93.2.472

Rousseau, D. M. (1995). Psychological contracts in organizations: Understanding written and unwritten agreements. Thousand Oaks, CA: Sage.

Schumacker, R. E., \& Lomax, R. G. (2010). A beginner's guide to structural equation modeling. Mahwah, NJ: Lawrence Erlbaum Associates.

Solinger, O. N., Van Olffen, W., Roe, R. A., \& Hofmans, J. (2013). On becoming (un)committed: A taxonomy and test of newcomer onboarding scenarios. Organization Science, 24(6), 1640-1661. https://doi.org/10.1287/orsc.1120.0818

Staw, B. M. (1974). Attitudinal and behavioral consequences of changing a major organizational reward: A natural field experiment. Journal of Personality and Social Psychology, 29(6), 742-751. https://doi.org/10.1037/h0036292

Sturges, J., Conway, N., Guest, D., \& Liefooghe, A. (2005). Managing the career deal: The psychological contract as a framework for understanding career management, organizational commitment and work behavior. Journal of Organizational Behavior, 26(7), 821-838. https://doi.org/10.1002/job.341

Tolentino, R. C. (2013). Organizational commitment and job performance of the academic and administrative personnel. International Journal of Information Technology and Business Management, 15(1), 51-59. Retrieved from http://www.jitbm.com/JITBM\%2015th\%20volume/5\%20Organization\%20Commitment.pdf

Turnley, W. H., Bolino, M. C., Lester, S. W., \& Bloodgood, J. M. (2003). The impact of fulfilment of the psychological contract on the performance of in-role and organizational citizenship behaviors. Journal of Management, 29(2), 187-206. https://doi.org/10.1177\%2F014920630302900204

Tzelgov, J., \& Henik, A. (1991). Suppression situations in psychological research: Definitions, implications, and applications. Psychological Bulletin, 109(3), 524-536. https://doi.org/10.1037//0033-2909.109.3.524 


\section{Authors}

\section{Leticia Gomes Maia}

Banco Central do Brasil

Setor Bancário Sul Q. 3 BL B, Asa Sul, 70074-900, Brasília, DF, Brazil

lgomesmaia@gmail.com

(iD) https://orcid.org/0000-0001-5123-6724

\section{Antonio Virgilio Bittencourt Bastos}

Universidade Federal da Bahia

Av. Reitor Miguel Calmon, s/n, Vale do Canela, 40110-903, Salvador, BA, Brazil antoniovirgiliobastos@gmail.com

iD https://orcid.org/0000-0002-1322-5749 